\title{
FIRST RECORD OF WEDGE SOLE, DICOLOGLOSSA CUNEATA (ACTINOPTERYGII: PLEURONECTIFORMES: SOLEIDAE), FROM THE LEVANT BASIN (EASTERN MEDITERRANEAN)
}

\author{
Malek ALI ${ }^{1}$, Adib SAAD ${ }^{1}$, Christian REYNAUD ${ }^{2}$, and Christian CAPAPÉ ${ }^{3 *}$ \\ ${ }^{1}$ Marine Sciences Laboratory, Faculty of Agriculture, Tishreen University, Lattakia, Syria \\ ${ }^{2}$ Laboratoire Interdisciplinaire de Recherche sur la Didactique, l'Éducation et la Formation, Université Montpellier \\ II, Sciences et Techniques du Languedoc, Montpellier, France \\ ${ }^{3}$ Laboratoire d'Ichtyologie, Université Montpellier II, Sciences et Techniques du Languedoc, Montpellier, France
}

Ali M., Saad A., Reynaud C., Capapé C. 2015. First record of wedge sole, Dicologlossa cuneata (Actinopterygii: Pleuronectiformes: Soleidae), from the Levant Basin (eastern Mediterranean). Acta Ichthyol. Piscat. 45 (4): 417-421.

\begin{abstract}
This paper reports the first record of a specimen of wedge sole, Dicologlossa cuneata (Moreau, 1881), from the Syrian coast, and also from the Levant Basin, constituting its easternmost extension range in the Mediterranean Sea. The specimen was examined, illustrated, measured, and weighed and the collected data are provided herein. This single capture of $D$. cuneata, however, cannot support a statement that a sustainable population of this fish has established itself in this area.
\end{abstract}

Keywords: description, morphometric measurements, meristic counts, distribution, extension range

Wedge sole, Dicologlossa cuneata (Moreau, 1881), has been reported in the eastern Atlantic from the Bay of Biscay (Lagardère 1980), the coast of Portugal (López et al. 2012) to south-western Spain (Jiménez et al. 1998, García-Isarch et al. 2006). South the Strait of Gibraltar, D. cuneata is known from Morocco (Belghyti et al. 1994, Lloris and Rucabado 1998), Mauritania (Maurin and Quéro 1981), Senegal (Cadenat 1951) to the Gulf of Guinea (Blache et al. 1970), and southward off the South Africa coast (Smith and Heemstra 1986).

Dicologlossa cuneata occurs in the Mediterranean Sea (Quéro et al. 1986) and the species was previously a main target species off the Spanish coast (Jiménez et al. 1998, García-Isarch et al. 2006), and due to a high fishing pressure, it is considered at present a threatened species in the area (Munroe and Nielsen 2010). Quéro et al. (1986) did not report the occurrence of D. cuneata from the Mediterranean coast of France and the Italian marine waters. Dicologlossa cuneata is reported off the Maghreb shore, from Morocco (Lloris and Rucabado 1998) and Algeria where it appears to be commonly caught (Rousset and Marinaro 1983, Boufersaoui and Bedda 2011); conversely, the species is not recorded off the Tunisian coast (Bradai et al. 2004). Dicologlossa cuneata is known off Greece (Papaconstatinou 2014) and
Turkey (Bilecenoğlu et al. 2014), displaying the extension range of the species in the eastern Mediterranean, although it was not recorded in the Levant Basin (Mouneimne 1977, Golani 2005, Saad 2005).

On 12 May 2014, a specimen of Dicologlossa cuneata was caught by bottom longline on sandy bottom at a depth of approximately $35 \mathrm{~m}, 3 \mathrm{~km}$ off Jableh city $\left(35^{\circ} 34^{\prime} \mathrm{E}\right.$, $35^{\circ} 20^{\prime} \mathrm{N}$ ) (Fig. 1). The specimen was measured to the nearest $1 \mathrm{~mm}$ and weighed to the nearest $1 \mathrm{dg}$. Biometric examination of the fish was based on the methodology of Quéro et al. (1986, 2003) and Louisy (2002). The weight, the morphometric measurements, and the meristic counts were summarized in Table 1. The morphometric measurements were provided as absolute values [mm] as well as relative values expressed as percent of the total length (TL) and standard length (SL). The specimen was preserved in $10 \%$ buffered formalin and deposited in the Ichthyological Collection of the Marine Sciences Laboratory, Agriculture Faculty at Tishreen University, Syria, under the catalogue number: 2270 MSL (Fig. 2A, B).

Family SOLEIDAE

Genus Dicologlossa Chabanaud, 1927

Dicologlossa cuneata (Moreau, 1881)

\footnotetext{
* Correspondence: Dr Christian Capapé, Laboratoire d'Ichtyologie, case 104, Université Montpellier II, Sciences et Techniques du Languedoc, 34 095 Montpellier cedex 5, France, phone: +33 467544162, e-mail: (CC) capape@univ-montp2.fr, (SRN), (MA) malekali@scs-net.org, (AS) adibsaad52@gmail.com, (CR) reynaud@univ-montp2.fr.
} 
Diagnosis. Body oval and strongly compressed, broad anteriorly and tapering posteriorly, with snout prominent and rounded, ctenoid scales on eyed side, and cycloid scales on blind side; scales on head and nape of eyed side larger than those on body; eyes on right side, with scaly interorbital space, mouth curved, cleft reaching posteriorly only to vertical through middle of upper eye, supra-temporal branch of lateral line forming angular S-shape (Fig. 3), anterior nostril on blind size not enlarged, anterior nostril on eyed side with backward pointing tube, dorsal fin beginning at vertical through front margin of upper eye, dorsal and anal fins joined to caudal fin; pectoral fins symmetrical in size; pelvic fins short and bases asymmetrical in position; colour grey or brown on eyed side of body greyish, blind side whitish, dark blotch on pectoral fin from eyed side.

Remarks. Morphology, colour, morphometric measurements, and counts observed in this specimen are in total accordance with Quéro et al. (1986, 2003) and Louisy (2002) and confirm the occurrence of Dicologlossa cuneata in the Syrian waters, increasing the number of bony fishes already recorded in the area (Saad 2005, Ali et al. 2013, 2014, Soliman et al. 2014). The addition of $D$. cuneata to the Syrian ichthyofauna makes it the second representative of its genus in the Mediterranean. The other one is ocellated wedge sole, Dicologlossa hexophthalma (Bennett, 1831) recorded to date off the Mediterranean Spanish coast (Quéro et al. 1986). It is therefore necessary to provide a key to distinguish between $D$. cuneata and D. hexophthalma, based on morphology, colour, and meristic counts.
Taxonomic key. (The values recorded in the Syrian specimen of $D$. cuneata are given in square brackets.)

Body oval, tapering backward, dorsal fin with 77-90 [82] fin rays, pectoral fin on eyed side with 8-10 [8] fin rays, on blind side a little shorter with 7-10 [7] fin rays,

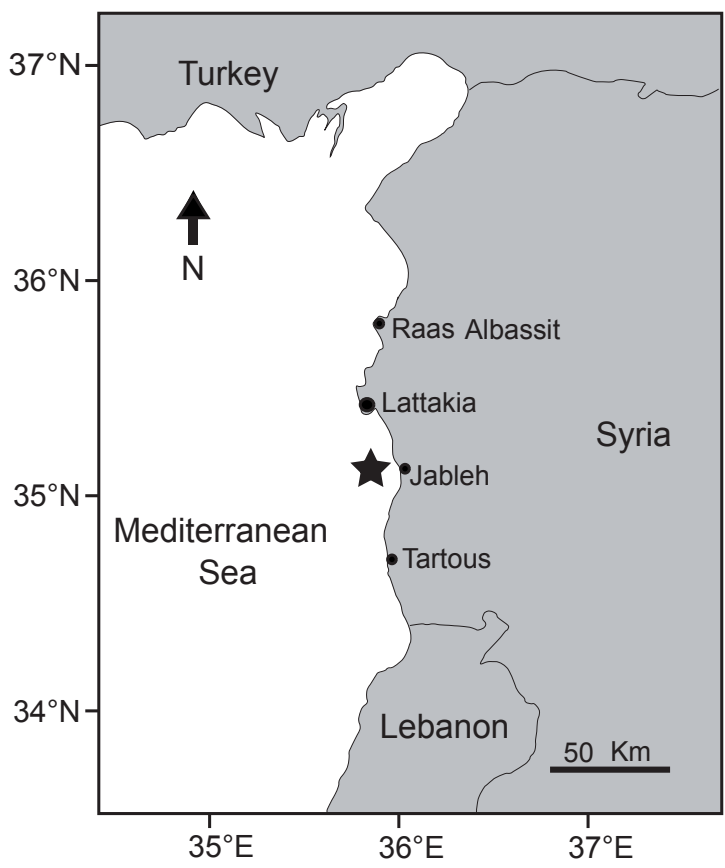

Fig. 1. Map of the Mediterranean showing Syria and map of the coast of Syria pointing out the capture site of $D i$ cologlossa cuneata (black star)

Table 1

Absolute and relative biometric data of the specimen of Dicologlossa cuneata from the Syrian coast

\begin{tabular}{|c|c|c|c|c|c|}
\hline \multirow{2}{*}{ Character } & \multicolumn{5}{|c|}{ Value } \\
\hline & Count & {$[\mathrm{mm}]$} & {$[\% \mathrm{TL}]$} & {$[\% \mathrm{SL}]$} & {$[\mathrm{g}]$} \\
\hline Total length (TL) & & 232 & 100.0 & 120.2 & \\
\hline Standard length (SL) & & 193 & 84.1 & 100.0 & \\
\hline Body depth & & 68 & 29.3 & 35.2 & \\
\hline Interorbital space & & 3 & 1.3 & 1.5 & \\
\hline Pre-pelvic length & & 23 & 9.9 & 11.8 & \\
\hline Pre-anal length & & 36 & 15.5 & 18.5 & \\
\hline Dorsal fin length & & 198 & 85.3 & 101.5 & \\
\hline Dorsal fin base & & 195 & 84.1 & 100.0 & \\
\hline Dorsal fin height & & 12 & 5.2 & 6.2 & \\
\hline Anal fin length & & 168 & 72.4 & 86.2 & \\
\hline Anal fin base & & 165 & 71.1 & 84.6 & \\
\hline Anal fin height & & 9 & 3.9 & 4.6 & \\
\hline Dorsal fin soft rays & 82 & & & & \\
\hline Pelvic fin soft rays E/B & $7 / 7$ & & & & \\
\hline Anal fin soft rays & 67 & & & & \\
\hline Pectoral fin soft rays E/B & $8 / 7$ & & & & \\
\hline Caudal fin soft rays & 16 & & & & \\
\hline Lateral line scales E/B & $125 / 130$ & & & & \\
\hline Supratemporal lateral line scales E/B & $23 / 0$ & & & & \\
\hline Weight & & & & & 120.6 \\
\hline
\end{tabular}

Measurements are expressed in millimetres or as percentage of total length or standard length; $\mathrm{E} / \mathrm{B}=$ value for eyed/blind side. 


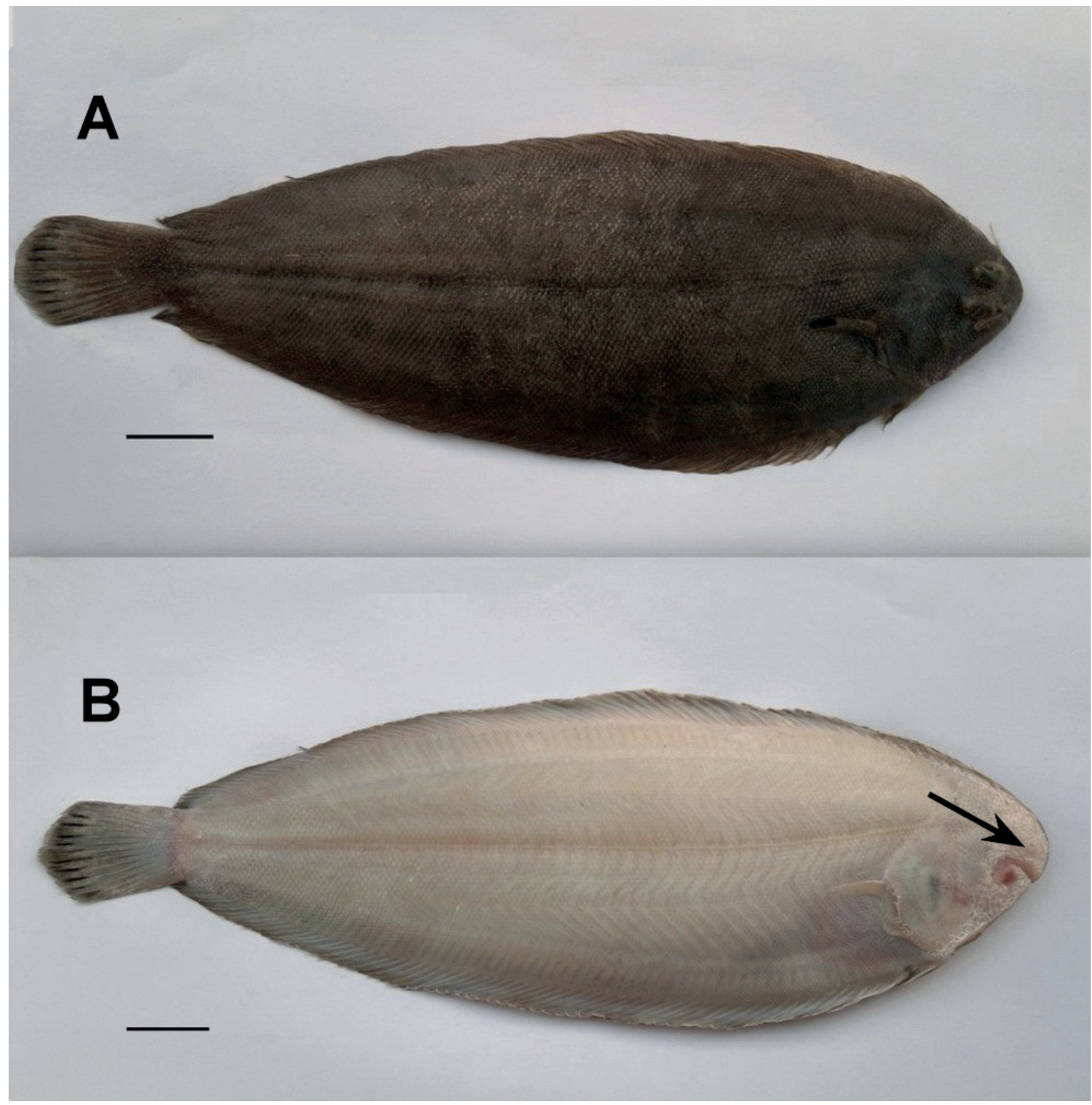

Fig. 2. Dicologlossa cuneata captured off the Syrian coast; Eyed side (A), scale bar $=20 \mathrm{~mm}$; Blind side (B) with arrow showing anterior nostril, scale bar $=20 \mathrm{~mm}$

anal fin with 62-78 [67] fin rays, caudal fin united to dorsal by a little developed membrane, lateral line with 114 126 [125] scales; colour of eyed side grey or brown to chocolate, pectoral fin on eyed side with an oblong black blotch in the middle. Dicologlossa cuneata

Body strongly oval, dorsal fin with 61-71 fin rays, pectoral fin on eyed side with 8-10 fin rays, on blind side a little shorter with 3-7 fin rays, anal fin with 52-56 fin rays, caudal fin separated from dorsal lateral line with 90-92 fin rays; colour of eyed side reddish-brown, with dark bands and 6 dark ocelli, along dorsal and anal fins.

Dicologlossa hexophthalma

The presently reported capture of Dicologlossa cuneata constitutes the first record of the species in the Levant Basin and the Syrian coast, consequently it should be considered to date as the easternmost extension range of the species in the Mediterranean Sea. However, this single record does not constitute a sufficient support to suggest that a sustainable population is a present established off Syria, such as in other Mediterranean areas, southern Spain (Jiménez et al. 1998, García-Isarch et al. 2006), and the Algerian coast (Boufersaoui and Bedda 2011), being the best examples of stable populations. Although D. cuneata was not reported by Golani et al. (2002) as a 'Herculean alien species' (sensu Quignard and Tomasini 2000), a migration from the eastern Atlantic through the Strait of Gibraltar remains the most suitable hypothesis which cannot be totally ruled out. 


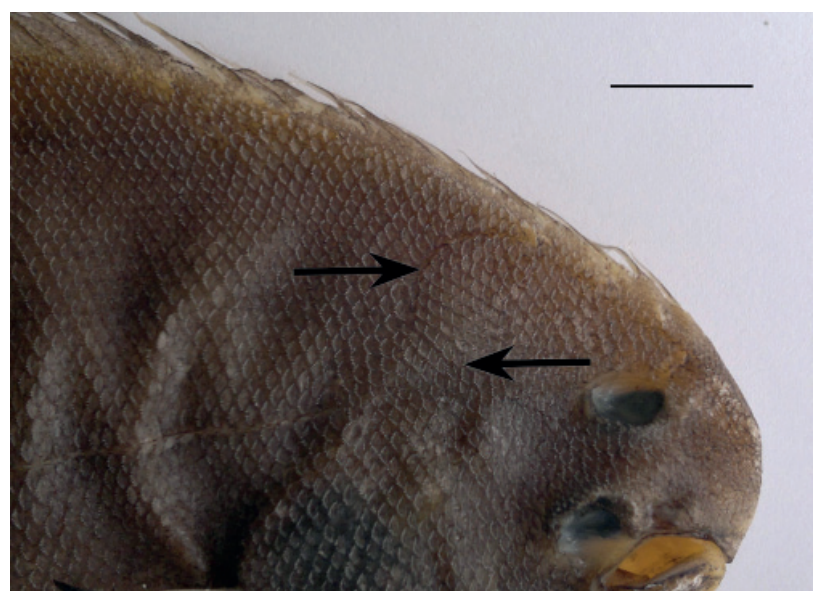

Fig. 3. Head of Dicologlossa cuneata; Eyed side with arrows showing supra-temporal branch of lateral line forming an angular S-shape; scale bar $=10 \mathrm{~mm}$

\section{REFERENCES}

Ali M., Saad A., Reynaud C., Capapé C. 2013. First records of Randall's threadfin bream Nemipterus randalli (Osteichthyes: Nemipteridae) off the Syrian coast (eastern Mediterranean). Annales, Series Historia Naturalis 23 (2): 119-124.

Ali M., Saad A., Reynaud C., Capapé C. 2014. First records of barracudina Sudis hyalina (Osteichthyes: Paralepididae) off the Syrian coast (eastern Mediterranean). Journal of Ichthyology 54 (10): 786-789. DOI: $10.1134 / \mathrm{S} 0032945214100026$

Belghyti D., Berrada-Rkhami O., Boy V., Aguesse P., Gabrion C. 1994. Population biology of two helminth parasites of flatfishes from the Atlantic coast of Morocco. Journal of Fish Biology 44 (5): 1005-1021. DOI: 10.1111/j.1095-8649.1994.tb01272.x

Bilecenoğlu M., Kaya M., Cihangir B., Çiçek E. 2014. An updated checklist of the marine fishes of Turkey. Turkish Journal of Zoology 38 (6): 901-929. DOI: 10.3906/zoo-1405-60

Blache J., Cadenat J., Stauch A. (eds.) 1970. Clés de détermination des poissons de mer signalés dans l'Atlantique oriental entre le $20^{\mathrm{e}}$ parallèle Nord et le $15^{\mathrm{e}}$ parallèle Sud. Faune tropicale 18. ORSTOM, Paris, France.

Boufersaoui S., Bedda M. 2011. Citharus linguatula et Dicologlossa cuneata des côtes algériennes: contribution à l'étude de la croissance et de l'exploitation. Éditions Universitaires Européennes, Saarbrücken, Germany.

Bradai M.N., Quignard J.-P., Bouain A., Jarboui O., Ouannes-Ghorbel A., Ben Abdallah L., Zaouali J., Ben Salem S. 2004. Ichtyofaune autochtone et exotique des côtes tunisiennes: Recensement et biogéographie. Cybium 28 (4): 315-328.

Cadenat J. 1951. Poissons de mer du Sénégal. Initiations Africaines de l'Institut Français d'Afrique noire de Dakar 3: 1-345.

García-Isarch E., Juárez A, Ruiz J., Romero Z., Jiménez P., Baldó F. 2006. Spawning and nurs- ery habitat of the wedge sole Dicologlossa cuneata (Moreau, 1881) in the Gulf of Cádiz (SW Spain). Scientia Marina 70 (Suppl. 2): 123-136.

Golani D. 2005. Checklist of the Mediterranean Fishes of Israel. Zootaxa 2005 (947): 1-200.

Golani D., Orsi-Relini L., Massuti E., Quignard J.-P. 2002. CIESM Atlas of exotic species in the Mediterranean. Vol. 1 . In: Briand F. (ed.). Fishes. CIESM Publications, Monaco.

Jiménez M.P., Sobrino I., Ramos F. 1998. Distribution pattern, reproductive biology, and fishery of the wedge sole Dicologlossa cuneata in the Gulf of Cadiz, southwest Spain. Marine Biology 131 (1): 173-187.

DOI: $10.1007 / \mathrm{s} 002270050308$

Lagardère F. 1980. Développement du céteau, Dicologlossa cuneata (Moreau) (Poissons-Soleidae) I. Description des oeufs, évolution des critères systématiques et chronologie du développement. Cybium 3 (11): 61-81.

Lloris D., Rucabado J. 1998. Guide FAO d'identification des espèces pour les besoins de la pêche.Guide d'identification des ressources marines vivantes pour le Maroc. FAO, Rome.

López J.R., Diéguez A.L., Doce A., De la Roca E., De la Herran R., Nava J.I., Toranzo A.E., Romalde J.L. 2012. Pseudomonas baetica sp. nov., a fish pathogen isolated from wedge sole, Dicologlossa cuneata (Moreau). International Journal of Systematic and Evolutionary Microbiology 62 (4): 874-882. DOI: $10.1099 /$ ijs.0.030601-0

Louisy P. 2002. Guide d'identification des poissons marins Europe et Méditerranée. Ulmer édition, Paris, France.

Maurin C., Quéro J.-C. 1981. Poissons des côtes nordouest africaines (Campagnes de la "Thalassa" 1962, 1968, 1971 et 1973); Saccopharyngiformes, Anguilliformes, Beryciformes, Zeiformes, Lampridiformes et Gasterosteiformes. Revue des Travaux de l'Institut des Pêches Maritimes 45 (1): 5-71.

Mouneimne N. 1977. Liste des poissons de la côte du Liban (Méditerranée orientale). Cybium 1: 37-66.

Munroe T.A., Nielsen J.G. 2010. Dicologlossa cuneata. In: Anonymous (ed.) The IUCN Red List of threatened species. [Version 2014.3.] [Accessed on 25 February 2015.] www.iucnlist.org

Papaconstantinou C. 2014. Fauna Graeciae. An updated list the fishes of the Hellenic Seas. Monographs on Marine Species 7. National Centre for Marine Reasearch (HCMR).

Quéro J.-C., Desoutter M., Lagardère F. 1986. Soleidae. Pp. 1308-1324. In: Whitehead P.J.P., Bauchot, M.-L., Hureau J.-C., Nielsen J., Tortonese E. (eds.) Fishes of the North-western Atlantic and the Mediterranean. Vol. III. UNESCO, Paris.

Quéro J.-C., Porché P., Vayne J.J. 2003. Guide des poissons de l'Atlantique européen. Les Guides du naturaliste. Delachaux and Niestlé, Lonay, Switzerland-Paris, France. 
Quignard J.-P., Tomasini J.A. 2000. Mediterranean fish Saad A. 2005. Check-list of bony fish collected from biodiversity. Biologia Marina Mediterranea 7: 1-66.

Rousset J., Marinaro J.Y. 1983. Croissance de Dicologlossa cuneata (Moreau) (Téléostéen Soléidé) sur les côtes d'Algérie. Rapports et Procès-Verbaux de la Réunion de la Commission internationale pour 1'Exploration scientifique de la Mer Méditerranée 28 (5): 77-79.

Smith M.C., Heemstra P.C. 1986. Smiths'sea fishes. Springer-Verlag, Berlin, Heidelberg, New York, London, Paris, Tokyo. the coast of Syria. Turkish. Journal of Fisheries and Aquatic Sciences 5 (2): 99-106.

Soliman A., Ali M., Saad A., Reynaud C., Capapé C. 2014. First records of sideburn wrasse Pteragogus pelycus (Osteichthyes: Labridae) off the Syrian coast (eastern Mediterranean). Annales, Series Historia Naturalis 24 (1): 23-28.

Received: 6 March 2015

Accepted: 27 July 2015

Published electronically: 31 December 2015 